\title{
ENERGY COST AND MOTIVATION IN A POPULATION OF YOUNG SWIMMERS
}

\author{
CUSTO ENERGÉTICO E MOTIVAÇÃO EM UMA POPULAÇÃO DE JOVENS NADADORES \\ COSTO ENERGÉTICO Y MOTIVACIÓN EN UNA POBLACIÓN DE JÓVENES NADADORES
}

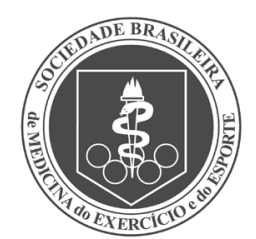

Artigo Original

\author{
José Maria Cancela Carral ${ }^{1}$ \\ (Licenciado en Ciencias do Desporto) \\ Carlos Ayán Pérez (Licenciado en \\ Ciencias do Desporto) \\ Carlos Montero Prieto' (Licenciado \\ en Ciencias do Desporto) \\ 1. Facultad de Ciencias de \\ la Educación y del Deporte. \\ Universidad de Vigo. Pontevedra, \\ Pontevedra, España.
}

\section{Correspondence:}

Facultad de Ciencias de la Educación y del Deporte. Universidad de Vigo. Campus A Xunqueira s/n 36005. Pontevedra, España.chemacc@uvigo.es

\begin{abstract}
Objective: To examine the relationship between the energy cost implied in competition in different swimming events and its relationship with motivation to practice this sport. Methods: A total of 389 swimmers (192 boys and 197 girls), aged 8-22 years, who competed in events with different energy demands responded to the Spanish versions of the Participation Motivation Inventory. Results: A multivariate analysis showed that the energy cost of the preferential event had a significant influence on the swimmer motivation (Wilk's $\lambda=0.96, F_{7,388}=6.29, P<0.005$ ). A later univariate analysis showed that the motivation of swimmers in predominantly aerobic modalities, as compared to those in anaerobic ones, was significantly influenced by four motivational components: "Health/Fitness", "Fun/Friendship", "Competition/Skills" and "Significant Others". The motivational factors also varied according to gender and stage of sport development of the swimmers. Conclusion: The results of this study show signs that the motivational factors related to the practice of competitive swimming in young athletes behaves differently depending on the energy cost of the test carried out.
\end{abstract}

Keywords: swimming, adolescent, motivation, energy metabolism, sports performance.

\section{RESUMO}

Objetivo: Analisar a relação entre o custo energético implícito na competição em diferentes eventos de natação e sua relação com a motivação para a prática desse esporte. Métodos: Um total de 389 nadadores (192 meninos e 197 meninas), com idades entre 8 e 22 anos, que competiram em eventos com diferentes demandas de energia respondeu às versões em espanhol do Inventário de Motivação para a Participação. Resultados: A análise multivariada demonstrou que o custo energético do evento preferido teve influência significante sobre a motivação dos nadadores ( $\lambda$ de Wilkis $\left.=0,96, F_{7.388}=6,29, P<0,005\right)$. Uma análise univariada posterior mostrou que a motivação dos nadadores nas modalidades predominantemente aeróbias, em comparação com as anaeróbias, foi significativamente influenciada por quatro componentes motivacionais: "Saúde/Boa forma física", "Diversão/Amizade", "Competição/Habilidades" e "Pessoas significantes". Os fatores motivacionais também variaram de acordo com o sexo e o estágio de desenvolvimento desportivo dos nadadores. Conclusão: Os resultados deste estudo mostram sinais de que os fatores motivacionais relacionados com a prática da natação competitiva em jovens atletas comportam-se de forma diferente, dependendo do custo energético do teste realizado.

Descritores: Natação; Adolescente; Motivação, Metabolismo energético, Desempenho atlético.

\section{RESUMEN}

Objetivo: Examinar el relacionamiento entre el costo energético implicado en la competición en diferentes eventos de natación y su relacionamiento con la motivación para la práctica de este deporte. Métodos: Un total de 389 nadadores (192 masculinos y 197 femeninos), con edad entre 8-22 años, que competían en eventos con diferentes demandas de energía respondieron a las versiones en Español del Inventario de Motivación para la Práctica. Resultados: Un análisis multivariado mostró que el costo energético del evento preferencial tuvo una influencia significativa en la motivación de los nadadores (Wilk's $\lambda=0,96, F_{7.388}=6,29, P<0,005$ ). Un análisis univariado posterior mostró que la motivación de los nadadores en modalidades predominantemente aeróbicas, comparada con aquellas anaeróbicas, fue significativamente influenciada por cuatro componentes motivacionales: "Salud/Aptitud", "Diversión/Amistad", "Competición/Habilidades", y "Otros Significativos". Los factores motivacionales también variaron de acuerdo al género y nivel de desarrollo deportivo de los nadadores. Conclusión: Los resultados en este estudio muestran señales del hecho de que los factores motivacionales en la práctica de natación competitiva en jóvenes atletas se comporta de formas diferentes, dependiendo del costo energético del test realizado.

Palabras clave: natación, adolescente, motivación, metabolismo energético, desarrollo deportivo. 


\section{INTRODUCTION}

The reasons why young people practice competitive sport have been under study in recent years ${ }^{1-6}$. From these studies several factors which have been identified are believed to have a determinant influence when it comes to selecting the type of sport category that is practiced. The main ones are age ${ }^{7}$, gender ${ }^{8}$, motor perceived level ${ }^{9}$ and even competitive $\mid$ level $^{8}$. In this direction, it has also been observed that the choice of a type of sport discipline, within the same sport, depends in turn on other factors which are mainly motivational, such as competence (related motives), skill abilities, fun, affiliation or social reasons ${ }^{10}$. Nevertheless, little is known about the role of the energy expenditure of a sport discipline on children's decision to take up and go on with its practice ${ }^{11,12}$.

Swimming is a sport whose motivational factors, considered as determinant to take it up at a competitive level, have been widely studied ${ }^{2,4,7,13}$. In spite of this, and taking into account that its performance requires a great physical and mental effort ${ }^{14,15}$, it is quite surprising that the identification of the energy expenditure on the performance of a particular modality of swimming competition as an evident motivational influence is still unclear.

Swimming as a sport covers a large number of events whose energy expenditure suffers a significant variation basically according to the distance and to a lesser extent, the style. This wide range of competitive modalities makes it compulsory for swimmers to start a process of early specialization ${ }^{16}$. The target of this process is to direct their technical, psychic and, specially, physical training according to their preferred modality of swimming competition. For this reason, and providing that swimming is an individual sport whose performance level depends to a great extent on the bioenergetic factor ${ }^{17,18}$, it makes sense that the motivation of the young swimmer will depend basically on the characteristics of the preferred event.

Under these circumstances, the objective of this study is to find out whether the motivation towards competitive swimming performance depends on the kind of event performed and the resulting energetic expenditure. Specifically, this research work arises with the intention of examining the relationship between the energy demand involved in competitive swimming events and the motivation each swimmer has to perform them.

\section{MATERIALS AND METHODS}

The swimmers were invited to take part in this study through a letter issued from the Facultad de Ciencias de la Educación y del Deporte. Universidad de Vigo to the Galician Swimming Federation. The coaches of 26 clubs agreed to participate in the study and recruited competitive swimmers from their teams, after having obtained their informed consent. The protocol was approved by the Local ethics committee.

The swimmers were distributed in three groups according to the energy demand of the preferential event in which they competed ${ }^{19}$. Thus, Group Ae consisted of swimmers who competed in distances from 400 to $1.500 \mathrm{~m}$, where the main source of energy came from the aerobic oxidative system, while those who competed in distances from 100 to 200 m (anaerobic glycolytic system), were included in Group An. Finally, the swimmers whose competitive success depended basically on the energy supplied by the high energy phospagen system (distance from 25 to $50 \mathrm{~m}$ ), were included in Group Ps. In order to determine the sports phase influence on the motivation of the swimmers three stages were distinguished according to the developmental model of sport participation ${ }^{20,21}$.

A Spanish validated version of "Participation Motivation Inventory"
(PMI) ${ }^{22}$ was used to assess motivation towards competitive swimming. The PMI questionnaires consist of a list of 32 possible reasons for participating in sports. Respondents are asked to rate on a five-point Likert scale, ranging from one (not at all important) to five (extremely important). The reliability and validity of the instrument had been previously established ${ }^{4}$.

The information linked to the preferential competitive event was collected by means of three questions; competing category, preferential event and best personal record on such event.

The data collection took place during the months of April-May 2011 and it was carried out during the clubs league. The researchers collected the information in a meeting room away from the pool deck at a time other than the regular workout time. During the meeting the research objective was explained and they were asked if they were so kind to answer a number of questions about the reasons why they practiced swimming. A period of time of 25 min was given to answer the PMI scale and the questions about the competitive events. The researchers helped the younger children to interpret the questionnaires when necessary.

\section{Statistics}

To estimate whether participation motives were associated with energetic cost of the preferential event, factors scores were calculated for all seven factors of the PMI, and used as dependent variables in a one-way multivariable analysis of variance. Significant multivariate effects were followed with univariate analysis. Correlations between scores in the seven scales of the PMI and energetic cost were calculated through Pearson correlation coefficients. In order to estimate effects of the gender and age on participation motives and energetic cost, a two ways multivariate analyses of variance were performed. Statistics were analyzed with SPSS for Windows (version 15.0; Chicago, Illinois).

\section{RESULTS}

A total of 389 swimmers took part in the research (Table 1), and filled out the PMI. The obtained data after a multivariate analysis showed that the energetic cost of the preferential swimming event had a strong influence on the swimmer's motivation (Wilk's $\lambda=0.96$, $\left.F_{7,388}=6.29, P<0.005\right)$. A subsequent univariate analysis revealed the existence of significant differences in 4 motivational components: "Health/ Fitness", "Fun/Friendship", "Competition/Skills" and "Significant Others". Post-hoc comparisons between the variables analyzed in the three groups (Table 2) confirmed these significant differences for swimmers in Group Ae as compared with those in Group Ps. In the same way, significant differences were also found for Group Ae, as compared with Group An in these four and in two more motivational components ("Affiliation" and "Status").

Table 1. Characteristics of the three groups of swimmer.

\begin{tabular}{c|c|c|c}
\hline & Group Ps & Group An & Group Ae \\
\hline $\mathrm{n}$ & 99 & 161 & 129 \\
\hline Age (Years old) & $15.47 \pm 3.34$ & $15.29 \pm 2.97$ & $15.06 \pm 3.08$ \\
\hline Gender & $53.6 \%$ men & $50.8 \%$ men & $49.4 \%$ men \\
\hline Training sessions per week & 4.0 & 4.0 & 4.0 \\
\hline \multicolumn{2}{c|}{ Group Ps: high energy phospagen system; Group An: anaerobic metabolism system; Group Ae: aerobic me- }
\end{tabular}
tabolism system. 
A two (gender) per three (energy costs) between-swimmers MANOVA was conducted on the participation motivational factors. The analysis revealed a significant multivariate effect for gender, Wilk's $\lambda=0.95$, $F_{7,365}=5.16, P<0.024$, but the gender by energy cost was not significant, Wilk's $\lambda=0.96, F_{14.719}=0.80, P>0.05$. Follow-up univariate analyses yielded significant differences between boys and girls for "Health/Fitness", "Competition/Skills", "Affiliation", and "Status".

The swimmers sport phase (age interval) was noted to be strongly influenced by the participation motivational factors (Wilk's $\lambda=0.96$, $\left.F_{21,1095}=7.13, P<0.001\right)$. Univariate analysis revealed significant differences between the different age groups for four participation motives: "Health/ Fitness", "Significant Others", "Affiliation" and "Status" (Table 3).

Table 2. Post-hoc comparison (newman-keuls test) of participation motives according to the energetic cost of the preferential event.

\begin{tabular}{c|c|c|c|c|c|c}
\hline \multirow{2}{*}{ Factor } & \multicolumn{2}{|c|}{ Group PS } & \multicolumn{2}{c|}{ Group PS } & \multicolumn{2}{c}{ Group An } \\
\cline { 2 - 7 } & \multicolumn{2}{|c|}{ Group An } & \multicolumn{2}{c}{ Group Ae } & \multicolumn{2}{c}{ Group Ae } \\
\cline { 2 - 7 } & $\%$ & $\mathbf{p}$ & $\%$ & $\mathbf{p}$ & $\%$ & $\mathbf{p}$ \\
\hline Health/fitness & -0.41 & 0.850 & 6.22 & 0.019 & 6.65 & 0.005 \\
\hline Fun/friends hip & 0.18 & 0.912 & 6.53 & 0.007 & 6.35 & 0.005 \\
\hline Competition/skills & -0.79 & 0.743 & 8.12 & 0.002 & 8.98 & 0.001 \\
\hline Significant others & $-2,66$ & 0.408 & 7.30 & 0.037 & 10.96 & 0.002 \\
\hline Affiliation & 1.65 & 0.450 & 4.87 & 0.044 & 3.17 & 0.135 \\
\hline Status & 2.20 & 0.513 & 7.36 & 0.049 & 5.04 & 0.177 \\
\hline Energy release & -0.80 & 0.821 & 3.64 & 0.387 & 4.50 & 0.231 \\
\hline
\end{tabular}

\%: percentage difference between both groups: Group Ps: high energy phospagen system; Group An: anaerobic metabolism system: Group Ae: aerobic metabolism system.

Table 3. Post-hoc comparison (newman-keuls test) of participation motives taken into account the swimmer's age interval.

\begin{tabular}{|c|c|c|c|c|c|c|}
\hline \multirow{3}{*}{ Factor } & \multicolumn{2}{|c|}{$<13$ Years old } & \multicolumn{2}{|c|}{$<13$ Years old } & \multicolumn{2}{|c|}{ 13-15 Years old } \\
\hline & \multicolumn{2}{|c|}{$13-15$ Years old } & \multicolumn{2}{|c|}{$>15$ Years old } & \multicolumn{2}{|c|}{$>15$ Years old } \\
\hline & $\%$ & $p$ & $\%$ & $p$ & $\%$ & $p$ \\
\hline Health/Fitness & -6.65 & 0.020 & -8.73 & 0.006 & -1.95 & 0.281 \\
\hline Fun/Friendship & -3.67 & 0.197 & -5.35 & 0.080 & -1.62 & 0.354 \\
\hline Competition/skills & 1.42 & 0.639 & -1.99 & 0.566 & -3.47 & 0.082 \\
\hline Significant others & -7.33 & 0.069 & -20.35 & 0.001 & -12.04 & 0.001 \\
\hline Affiliation & -4.91 & 0.089 & -10.51 & 0.001 & -6.17 & 0.001 \\
\hline Status & -6.20 & 0.156 & -19.19 & 0.001 & -12.22 & 0.001 \\
\hline Energy release & -4.67 & 0.273 & -7.42 & 0.130 & -2.40 & 0.394 \\
\hline
\end{tabular}

$\%$ : before percentage difference between both groups.

\section{DISCUSSION}

The debate is still open concerning the influence of the predominant energetic metabolism according to the physical exercise carried out over the motivation towards sport practice ${ }^{23}$, especially in young athletes. The results of this research show signs of a different behavior of the motivational factors towards the practice of competitive swimming. This difference is related to the energetic cost of the event carried out.

When the PMI factor scores were used as dependent variables in a one-way multivariate analysis of variance, a significant effect was detected indicating that the swimmers competing in aerobic events identified "Health/Fitness", "Fun/Friendship", "Competition/ Skills" and "Significant Others" as more important reasons for their swimming participation than did swimmers who competed in anaerobic events. Furthermore, signs of an inversely proportional tendency between energy demand of the swimming event and motivation were identified, as swimmers in Group Ae and in Group An obtained the highest and the lowest scores respectively in the PMI questionnaire. These findings confirm the fact previously observed which indicate that competition athletes who take part in endurance events show a higher motivation compared to those in "explosive" events $^{12}$. Although the reason for this different motivation towards competitive sport practice according to the metabolic demand of the test performed is still undetermined, some studies carried out with sedentary people can contribute with some ideas. Thus, it has been proposed that in aerobic activities the cognitive processes predominate in determining the acute affective response to exercise. Meanwhile, the higher the anaerobic component of the activity, the more prominence the interoceptive cues take ${ }^{24}$. In this line, it has been observed that exercise intensity that exceeds the point of transition from aerobic to anaerobic metabolism is accompanied by quadratic decline in affective valence ${ }^{25}$. Therefore, the affective and motivational response triggered by physical exercise is expected to vary according to its energetic cost.

Motivation towards competitive swimming also showed differences according to gender. Thus, the most important factors for boys were "Health/Fitness" and "Competition/Skills", and for girls "Affiliation" and "Status". This information has been previously observed in other studies carried out both with athletes of different sports ${ }^{12}$ and with swimmers ${ }^{4}$, and which proved that competitiveness and feeling good with oneself are the main motivational factors for men, while for women is friendship.

Another previously observed finding which is also confirmed in this study is the different influence of the motivational factors according to the stage of sport development where swimmers are ${ }^{26}$. In this way the "Health/Fitness" factor was noted to be especially significant at the beginning, and as the swimmers progress in their sporting life, other factors more connected to the social and affective environment, specifically "Affiliation", "Status" and "Significant Others", play an increasingly central role. In this respect, the age of the young athletes is known to be closely related to these factors ${ }^{4,7}$, which had been previously identified as specially relevant motivational factors in competitive swimmers ${ }^{27}$.

Methodological issues and limitation there are some limitations with the present research that should be noted. First, it should be mentioned the impossibility to find deeper causes of the associations among variables given the study's transversal design. A second limitation deals with the fact that the present sample was mainly composed of swimmers engaged in a regional competition. Finally, it should be noted the fact that a number of factors which affect the motivation 
of the swimmer (i.e. relationship with their family or coach) have not been analyzed. Further longitudinal studies with swimmer of higher competitive levels should take these aspects into consideration.

\section{CONCLUSIONS}

In summary, the obtained results on the sample of the analyzed Spanish swimmers indicate that the energetic cost of the event where they compete significantly affects the reasons to practice it. Nevertheless, there is a need to go on investigating in this direction as there is little evidence to contrast the obtained results.

Todos os autores declararam não haver qualquer potencial conflito de interesses referente a este artigo.

\section{REFERENCES}

1. Gill G, Gross J, Huddleston S. Participation motives in youth sports. Int J Sport Psychol. 1983;14(1):1-14.

2. Gould D, Feltz D, Weiss M. Motives for participating in competitive youth swimming. Int J Sport Psychol 1985. 16 (2), 126-40.

3. Klint K, Weiss MR. Dropping in and dropping out: Participation motives of current and former youth gymnasts. Can J Appl Sport Sci 1986. Jun;11(2):106-14.

4. Salguero A, Gonzalez-Boto R, Tuero C, Marquez S. Relationship between perceived physical ability and sport participation motives in young competitive swimmers. J Sports Med Phys Fitness. 2004;44(3):294-9.

5. Keegan R, Spray C, Harwood C, Lavallee D. The motivational atmosphere in youth sport: Coach, parent, and peer influences on motivation in specializing sport participants. J Appl Sport Psychol. 2010;22(1):87-105.

6. van de Pol PKC, Kavussanu M. Achievement motivation across training and competition in individual and team sports. Sport, Exercise, and Performance Psychology. 2012;1(2),91-105.

7. Brodkin P,Weiss M. Developmental differences in motivation for participating in competitive swimming. J Sport Exerc Psychol. 1990;12(3):248-63.

8. White, S. A., Duda, J. L., Sullivan, C. M., \& Liemohn, W. (1991). The relationships of gender, level of sport involvement, and participation motivation to goal orientation. In Abstracts of research papers presented Convention of American Alliance for Health, Physical Education, Recreation and Dance in the Research Consortium Meetings. San Francisco: American Alliance for Health, Physical Education, Recreation and Dance; 1991.

9. Ryckman RM, Hamel J. Perceived physical ability differences in the sport participation motives of young athletes. Int J Sport Psychol. 1993;24(3): 270-283.

10. Kolt G, Kirkby R, Bar-Eli M, et al. A cross-cultural investigation of reasons for participation in gymnastics./Enquete interculturelle des raisons de la participation en gymnastique. Int J Sport Psychol. 1999;30(3):381-98.

11. Viru M, Hackney AC, Karelson $K_{1}$ Janson $T$, Kuus M, Viru A. Competition effects on physiological responses to exercise: Performance, cardiorespiratory and hormonal factors. Acta Physiol Hung. 2010;97(1):22-30

12. Braathen E, Svebak S. Motivational differences among talented teenage athletes: The significance of gender, type of sport and level of excellence. Scand J Med Sci Sports. 1992;2(3):153-9.

13. Salselas V, González-Boto R, Tuero C, Márquez S. The relationship between sources of motivation and level of practice in young Portuguese swimmers. J Sports Med Phys Fitness. 2007;47(2):228-33.
14. Toussaint HM, Hollander AP. Energetics of competitive swimming. implications for training programmes Sports Med. 1994;18(6):384-405.

15. Fletcher D, Hanton S. The relationship between psychological skills usage and competitive anxiety responses. Psychol Sport Exerc. 2001;2(2):89-101.

16. Baker J. Early specialization in youth sport: A requirement for adult expertise? High Ability Studies 2003;14(1):85-94

17. Cancela J, Pariente S, Camina F, Lorenzo R. Tratado de natacion: Del perfeccionamiento al alto rendimiento. Barcelona: Paidotribo; 2008.

18. El Kady AEM. Effect of basic endurance training on the level of maximum oxygen consumption and the recorded achievement for junior swimmers $400 \mathrm{~m}$ freestyle stroke. World J Sport Sci. 2012;6(1):21-5.

19. Maglischo EW. Swimming even faster. Mayfield Mountain View, CA; 1993.

20. Fraser-Thomas J, Côté J, Deakin J. Youth sport programs: An avenue to foster positive youth development. Phys Educ Sport Pedagog. 2005;10(1):19-40.

21. Côté J, Fraser-Thomas J. Youth involvement in sport. In: Crocker E, ed. Introduction to sport psychology: A canadian perspective. Toronto: Pearson Prentice Hall; 2007:266-294.

22. Salguero A, Gonzalez-Boto R, Tuero C, Marquez S. Development of a spanish version of the participation motivation inventory for young competitive swimmers. Percept Mot Skills. 2003;96(2):637-46

23. Scully D, Kremer J, Meade MM, Graham R, Dudgeon K. Physical exercise and psychological well being: A critical review. Br J Sports Med. 1998;32(2):111-120.

24. Parfitt $G$, Rose EA, Burgess WM. The psychological and physiological responses of sedentary individuals to prescribed and preferred intensity exercise. Br J Health Psychol. 2006;11(1):39-53.

25. Ekkekakis P, Hall EE, Petruzzello SJ. Practical markers of the transition from aerobic to anaerobic metabolism during exercise: Rationale and a case for affect-based exercise prescription. Prev Med. 2004:38(2):149-59.

26. Fraser-Thomas J, Côté J, Deakin J. Understanding dropout and prolonged engagement in adolescent competitive sport. Psychol Sport Exerc. 2008;9(5):645-62.

27. Guillén García F, Alvarez Malé ML. Reasons for sport participation in competitive swimming in children and young athletes. Revista iberoamericana de psicología del ejercicio y el deporte. 2010;5(2):233-51. 